\title{
An Investigation of Difficulties Encountered by EFL Teachers in the Application of Strategies in Teaching Listening Skill
}

\author{
Truong Tuan Minh \\ Faculty of English Language Ho Chi Minh City University of Technology (HUTECH), Vietnam \\ Le Van Tuyen \\ Faculty of English Language Ho Chi Minh City University of Technology (HUTECH), Vietnam
}

\begin{abstract}
Recently English has been employed as a medium of instruction at the Vietnamese tertiary level. It is necessary to teach its students listening strategies to help them deal with the potential problems that may arise during listening or prepare them for their further educational purposes. This study, therefore, aims to explore the EFL teachers' perceptions of listening strategies and the application of listening strategies, and discover difficulties that they encounter in their instruction at a public university (henceforth called $P U$ ) in Ho Chi Minh City-Vietnam. Thirty six EFL teachers who were teaching English at PU were invited to participate in the study. Quantitative and qualitative data were obtained through two instruments, namely questionnaire and interview. The results revealed that not all the strategies were frequently employed for listening instruction. Several strategies were more frequently employed than the others; for example, cognitive, metacognitive and affective strategies were frequently integrated into instruction by the EFL teachers. Regarding the potential problems relating to listening lessons, the results showed that most of the EFL teachers had difficulties relating to professional development, students and teaching resources. This study is expected to shed light to the implementation of teaching listening strategies in PU context and in other similar contexts.
\end{abstract}

Keywords: Listening strategies; Instruction; Difficulties; Implementation; Tertiary level.

(9) (9) CC BY: Creative Commons Attribution License 4.0

\section{Background of the Study}

Listening is one of the vital learning channels in universities in which English is used as a medium of instruction due to the close relationship between lectures and teaching, learning activity in higher educational settings (Benson, 1994). In order to survive, particularly in the academic contexts, it is vital for students to be able to listen effectively for various reasons such as to follow the lectures or study abroad. That is why it is necessary to change the way of teaching listening comprehension in EFL contexts (Field, 2002).

Recently, a great deal of care and attention has been put into listening comprehension to help students enhance their listening skills. Apart from speaking writing and reading skills, there is also a growing interest in listening skills in terms of strategy-based instructions. However, Field (2002) states that there is a tendency among teachers to test listening rather than teach it and that practicing listening should be supported by teaching students how to listen because listening is a valuable source when it comes to second language acquisition and listening is regarded as a vital resource for language learning (Peterson, 2001; Rost, 2002). Despite the substantial role of listening in both SLA and learning content in an academic context, there seem to be a few relative studies examining the variety of aspects of listening in general (Ferris, 1998).

O'Malley et al. (1985) highlight the obvious benefits that arise from strategy-based instructions when it comes to foreign language listening comprehension. Similarly, other studies (Chamot, 1995; Mendelsohn, 1994; Oxford, 1990; Rubin, 1995) emphasize the vital necessity of teaching foreign language students listening strategies that are likely to help language students deal with the challenging listening tasks in the situations that they may encounter in their daily lives. Due to the considerable importance of strategy training mentioned above, it is necessary to incorporate learning strategies into language classes.

Researchers (ibid.) note that it is essential to build full awareness of listening strategies among students since they often employ in their first language (L1), and these effective techniques can also be successfully adapted to L2. Due to the need for explicit strategy training, the teacher is often regarded as a crucial factor in language teaching. Richards (1996) points out those teachers should be viewed as the core subject of studies when it comes to language teaching.

Many studies have attempted to investigate how to develop students' listening comprehension (Vandergrift, 1999), listening strategies used by the students (Goh, 2002), students' listening comprehension problems (Demirkol, 2009; Goh, 2002; Graham, 2006). These studies primarily focused on students' listening comprehension problems based on students' perceptions of the challenges they faced in listening. Nonetheless, difficulties that EFL teachers may encounter when teaching EFL listening comprehension in universities in Vietnam seem not to have been investigated by many researchers, especially how to teach listening strategies to EFL students. Therefore, there is obviously a lack of studies related to the EFL listening comprehension in those universities in which English is used 
as a medium of instruction in the Vietnamese context. As a result, it seems extremely urgent to search for the aspects of listening teaching that remains unknown to teachers, including the practices adopted at PU. It is expected that this study can be used to develop further knowledge on the topic.

\section{Purposes of the Study}

This study aims to investigate the difficulties encountered by EFL teachers in the application of strategies in teaching listening skill at PU. It attempts to find out EFL teachers' perceptions of listening comprehension strategies, explore the extent to which they teach listening comprehension strategies to the students, and discover difficulties they encounter in listening comprehension lessons.

\section{Research Questions}

The study attempted to address the three following questions:

1. How do EFL teachers perceive listening comprehension strategies?

2. To what extent do the EFL teachers teach listening comprehension strategies to the students?

3. What difficulties do the EFL teachers encounter in listening comprehension lessons?

\section{Significance of the Study}

The current study may make both theoretical and practical contributions. Theoretically, it is one of the very few studies conducted to investigate EFL teachers' difficulties in the application of listening strategies in teach EFL in Vietnam. Therefore, it may make a small contribution to the existing knowledge of the field of study, i.e., teaching EFL listening skill. Especially EFL listening skill often poses potential problems at the advanced level in tertiary contexts. The study can be used to develop further knowledge on the topic. Practically, knowing that teaching listening comprehension is a considerable challenge may help EFL teachers come up with possible solutions to improve their students' listening skill. Teachers can verify their current principles and practices of teaching in order to prepare materials or adapt listening activities in course books to meet students' needs and expectations.

\section{Literature Review}

\subsection{Definition of Listening Comprehension}

Researchers have given a variety of definitions of listening comprehension. According to Hamouda (2013) listening comprehension is an interactive process in which people both interact with one another and work out the meaning of the utterances made by their partners. Similarly, Nadig (1999) defines listening comprehension as many different processes during which spoken words such as sounds, words, grammatical structures, are made and comprehended. Likewise, listening comprehension is defined as a conscious and active process in which meaning is constructed by signals from contextual information and previous knowledge as well, and listener seems to depend on the number of strategic resources to accomplish the required tasks (O'Malley et al., 1989).Vandergrift (1999) defines listening as "a complex, active process in which the listener must discriminate between sounds, understand vocabulary and grammatical structures, interpret stress and intonation, retain what was gathered in all of the above, and interpret it within the immediate as well as the larger sociocultural context of the utterance". It is a psychological activity requiring the listener to coordinate.

It can be seen that all the above definitions of listening consider that listening is a process which requires listeners to interact with speakers, work out and understand meaning of the utterances. Thus, it is necessary to know about this process in order to identify the potential problems may arise from the listening.

\subsection{Teaching Listening Comprehension}

\subsubsection{Approaches to Teaching Listening Comprehension}

Researchers and educators have pointed out three approaches relating to the teaching of listening, they are oral approaches to language teaching, listening based language learning and communicative language teaching (Rost, 1990). First, oral approaches to language teaching highlight the discrimination and identification of language structures when listening. Next, listening based language learning emphasizes the importance of listening as an essential part that provides valuable input for learning language. The final approach, communicative language teaching, emphasizes the comprehension by listening to the input in the real world. Over 50 years, these approaches to listening have evolved, and Rost (2002) points out that there are connections between these existing approaches with the different areas such as education, linguistics, language acquisition and instructional design.

\subsubsection{Stages of Teaching Listening Comprehension}

There are three stages of an effective listening comprehension lesson; they are pre-listening, while-listening and post-listening. During pre-listening stage, teachers are supposed to provide students with real life like situations to motivate them to listen (Field, 2002). Furthermore, it is necessary to activate students' existing knowledge relating to the language and topic at this stage (Underwood, 1989). However, it is advisable to spend no more than five minutes during this stage since it may cause the loss of curiosity among students (Field, 2002). Pre-listening activities often involve in tasks such as brainstorming vocabulary, looking at the pictures, discussing the topic of the listening text (Field, 2002). In addition, at this stage, it is important to provide the purposes for the listening tasks rather than ask 
them to answer the questions that will occur at the next stage (ibid.). In other words, students should be informed of the comprehension questions that will be answered or what they are required to do when listening.

The while-listening stage consists of extensive and intensive listening (Field, 2002). Extensive listening is viewed as listening to a text for pleasure without focusing on the details. In contrast, during intensive listening, listeners try to obtain the detailed information from listening text (Rixon, 1986). Mendelsohn (1995) points out that it is necessary to expose students in a great deal of real life listening during a listening comprehension course; particularly, the extensive and intensive listening. Moreover, students may listen to a text more than once to compensate for the absence of visual and contextual clues (Ur, 1984). Furthermore, Underwood (1989) emphasizes that the purpose of the while-listening is to help the students acquire the suitable messages from the listening text. Thus, while-listening activities should be easy to complete and enjoyable to engage in since it is vital to motivate students rather than test their comprehension at this stage (ibid.). During this stage, students may be required to fill in a form, complete drawings or diagrams or to draw shapes on a picture (Field, 2002).

During the post-listening stage of listening lesson, it is necessary to assess whether the students' expectations are reached or what potential problems they may encounter. Furthermore, it depends on the students' aims to test their understanding at this stage. If the students' objective is to study for a listening comprehension test, it is suitable to ask multiple choice or other kinds of questions during this stage (Underwood, 1989). In addition, the teacher may integrate listening with other language skills such as group discussion or writing tasks (ibid.). Also, during this stage, the teachers are supposed to provide students with the immediate feedback on their answers since the relevant information still remains in their minds (ibid.).

\subsection{Potential Difficulties Arising from Teaching Listening Comprehension 5.3.1. Difficulties Related to Teachers' Proficiency}

Though there have been several studies on listening comprehension difficulties that students often encounter (Brown G., 1995; Higgins, 1996; Lonsdale, 1996; McNeill, 1996; Thompson, 1995; Ur, 1996), only a few writers mentioned the difficulties from the teachers' perspectives. According to Ho (2011), the difficulties related to the teachers may involve the differences in teachers' qualification, and teachers' teaching methods.

Hargreaves and Fullan (1992) stated that teachers are the ultimate key to educational changes and improvements. Teachers play a crucial role in both implementing and refining the curriculum. They comprehend the curriculum and make the learning process become more manageable for the students. In other words, it can be interpreted that teachers' practice can affect what students learn in the classroom. Therefore, it can be said that professional growth should be the top priority and teachers are supposed to constantly develop not only their knowledge of the subject they are teaching but also their pedagogical knowledge.

\subsubsection{Difficulties Related to Teaching Environment}

Chaugule (2009) claims that it is necessary to build up a suitable physical and psychological condition in classrooms in order to create a supportive environment and adequate facilities for developing teaching and encouraging students to learn. Since teaching listening often includes not only techniques, methods, materials, but also class organization. Classroom should be organized to encourage pair work, group work and interaction among students. Thus, large class size is often regarded as unsuitable for teaching and learning activities (Eltaib, 2011).

\subsubsection{Difficulties Related to the Teaching Materials}

A textbook is regarded as a published book aimed to help language students to enhance their linguistic and communicative abilities (Sheldon, 1987). Moreover, textbooks can be used as a supporting teaching tool (Ur, 1996). TextbookS often come together with workbooks or teacher's books (Masuhara and Tomlinson, 2008). They are "designed to give cohesion to the language teaching and learning process by providing direction, support and specific language based activities aimed at offering classroom practice for students". However, Swales (1980) argues that the increasingly wide use of the textbook may represent a perceived failure of education. Since textbooks may provide a general framework on how to deliver a lesson (Hutchison and Torres, 1994), many language teachers are likely to rely on the textbook and become less creative in teaching (Tomlinson, 2008). This may result in the believing among these teachers that the task and activities, providing by textbooks are usually better than their own ideas (McGrath, 2002). Though textbooks often provide students and teachers with a useful framework for learning and teaching, there is no textbook that can help deal with the various learning styles, individual needs, and the requirements of the classroom settings (Tomlinson, 2003; Ur, 1996). Moreover, in ELT contexts in which exam oriented culture remains largely like Vietnam, textbooks are often used as exam practice rather than a tool to promote successful language acquisition (Tomlinson, 2008).

\subsubsection{Difficulties Related to Students}

It can be seen that the difficulties related to students that teachers often encounter may arise from the problems that students usually face when listening in the classroom. Obviously, these difficulties have been studied by a number of scholars (Chen, 2002; Goh, 2000). They attempted to find out why listening comprehension is a challenging for EFL students and what factors affect listening comprehension.

Background knowledge: Underwood (1989) points out that lacking background knowledge and contextual knowledge are two of the most factors hindering students from understanding when listening. Lynch (2002) conclude that lacking of background knowledge often cause difficulty in listening comprehension. 
Phonological awareness: Problems such as sound stream division, sound discrimination, intonation and stress, syntax and phrase, and vocabulary are often considered as hindrances to listening comprehension (Yen, 1987). Similarly, Rixon (1986) concludes that the problems that EFL students usually face when it comes to listening comprehension is the way in which English words are pronounced. Word recognition: Unfamiliar words and inability to repeat these words are also regarded as factors affecting listening comprehension (Underwood, 1989). Similarly, Hasan (2000) argues that the factors such as long, complex texts, difficult grammatical structures, and unfamiliar words are often considered as the elements prevent students from understanding listening texts.

Sources of difficulty coming from the speaker: Not seeing the speaker's facial expressions and body gestures is also regarded as a factor that affects listening comprehension. Brown (1994) argues that there is a strong link existing between stressed syllables and speaker's body gestures. According to him, those body gestures are useful for students since stress is usually put on words which transfer the information of what has been said. Rixon (1981) argues that facial expressions and body movements strengthen the speaker's linguistic production. There are other factors relating to English accents that also prevent students from understanding, since different speakers speak with different accents and students often find it hard to understand the conversation with various accents (Juan and Abidin, 2013).

Sources of difficulty coming from the listener: Students often feel intolerant to incompleteness and vagueness, they tend to lose interest and feel anxious when they fail to understand every word of what has been heard (Underwood, 1989). And this constant anxiety arisen during the listening process may affect students' listening comprehension (King and Behnke, 2003). In addition, Ur (2000) points out that listening comprehension seems difficult for students since what they listen in the classroom is completely different from real life situations. Students are often allowed to listen to the text more than one in order to fulfill the task in the classroom. However, in their daily lives, when students listen to TV program, or radio, or take part in a real conversation, it may be impossible for them to catch up with what the speakers said.

\subsection{Listening Learning Strategies}

Chamot (1995) defined learning strategies are "the steps, plans, insights, and reflections that students employ to learn more effectively". Learning strategies are regarded as important as the remaining language skills since they are significant contributors to one's successful listening. They can increase success so long as they are chosen and applied in accordance with students' learning styles (Tauroza, 1997). Hasan (2000) points out that those successful language students often employ learning strategies effectively. Strategies are viewed as techniques combined with others to lower the level of anxiety and verify the comprehension (Vandergrift, 1999). Similarly, Rost (2002) concludes that strategies should be utilized consciously; in other words, students should determine the suitable occasion to apply the strategies to become successful.

It is believed that strategies should be integrated into listening lessons and teachers should teach their students effective strategies to help them deal with the difficulties they may encounter (Mendelsohn, 1995). Accordingly, a listening course with the strategy based approach often includes strategies either to determine setting, topic and meaning of spoken language or to make prediction and inferences.

Rost (2002) suggests five strategies that almost successful listeners often employ, they are predicting information or ideas prior to listening; making inferences from incomplete information based on prior knowledge; monitoring one's own listening process and relative success; attempting to clarify areas of confusion; and responding to what one has understood". Vandergrift (1999) claims that learning strategies are viewed as effective methods that help students become actively involved in controlling their own learning. He also points out that strategy development is necessary for listening training since these strategies assist students in guiding and evaluating their own learning.

O’Malley and Chamot (1990) subdivided these strategies into three groups: cognitive, metacognitive and social affective. This classification is widely accepted by several scholars (Peterson, 2001; Rost, 2002). Cognitive strategies involve comprehending the linguistic input and guessing the meaning from the texts; and include top down and bottom up strategies, involve understanding and storing information in the memory for later use (Goh, 2000); metacognitive strategies are regarded as mental activities that deal with learning how to plan, check, monitor, select, revise and evaluate; and social affective strategies are related to techniques that students use to interact with the others to verify comprehending or to lower anxiety. Oxford (1990) divides listening strategies into two groups: direct and indirect strategies. Indirect strategies consist of metacognitive which involves how students control their own learning; social strategies which involves how to interact with others while learning; and affective strategies which involves students' feelings. These strategies work as means of support and control language learning without directly intervening the target language. In contrast, direct strategies include cognitive strategies which involve how students concern about their own learning; compensation strategies which allow students to apply new language for understanding and productions in spite of their limited knowledge; and memory strategies which involve arranging and reviewing the language. These strategies directly involve the target language.

\section{Research Methods}

\subsection{Participants}

The participants of the study were 36 EFL teachers including 26 female and 10 male teachers. Their teaching experience ranges from 1 to 12 years; and their ages range from 24 to 40 . They teach listening skill to different levels. 18 of them teach pre-intermediate level; 10 of them teach the beginning level and 8 of them teach the 
intermediate level. The participants were randomly selected from a larger population of 50 EFL teachers at PU. All of them have Master's Degrees in English Education or TESOL.

\subsection{Instruments}

Two instruments including questionnaires, and interviews were employed to collect data for this study. The questionnaire consisted of three parts. The first part consisted of 7 items to elicit the participants' background information (items 1-4) and asked the participants about the usefulness of listening strategies and their familiarity with them (items 5-7).

The second part consisted of 32 items (items 1-32) were grouped into six categories asking the participants about the extent or frequency of using learning strategies. This part of the questionnaire employed a five point Likert scale ranging from Never $(\mathrm{N})$, rarely $(\mathrm{R})$, sometimes $(\mathrm{S})$, often $(\mathrm{O})$, and always $(\mathrm{A})$. The last part consisted of 33 items (items 33-65) and employed a five point Likert scale ranging from strongly disagree (SD), disagree (D), neutral $(\mathrm{N})$, agree $(\mathrm{A})$, strongly agree $(\mathrm{SA})$. The items were grouped into four categories: difficulties related to teacher's proficiency, difficulties related to the teaching environment, difficulties related to availability of resources and teaching aids, and difficulties related to students. All 65 items were both self-constructed and adapted based on (Alrawashdeh and Al-zayed, 2017; Graham, 2006; Juan and Abidin, 2013; King and Behnke, 2003; Ur, 2000; Yukselci, 2003). The data collected from the questionnaire were used to answer the three research questions. The interview consisted of six questions. It was conducted to complement the questionnaire and mostly address the first research.

\subsection{Data Collection}

Data collection took place during the second academic year 2017-2018. Firstly, through the consent forms the participants were informed of the purposes, requirements, and methods of the study to avoid any unnecessary confusion when completing the questionnaire. After that, 36 copies of the questionnaire were administered to them. The participants were allowed 30 minutes in total to complete the questionnaires. When the participants finished the researcher collected the copies and conducted an interview with ten teachers. Each interview lasted 10 minutes.

\subsection{Data Analysis}

Data obtained from the questionnaire were analyzed quantitatively by using SPSS, version 20. Basic statistical descriptions such as percentages (\%), means (M) and standard deviations (St. D) were used to analyze the participants' responses to address the three research questions. Descriptive statistics were used to find out the most and least frequently employed strategies and problems regarding listening strategy lessons at PU. The reliability coefficient of the questionnaire was measured as an indicator of homogeneity to the degree of instrument as a whole. Cronbach's alpha reliability calculated index for the questionnaire (65 items) was .889 , and this is a highly reliable rate. Regarding data collected from the interview, "content analysis" was employed. The data were transcribed and analyzed thematically. Each participating teacher was assigned the code T, for instance T1...T10.

\section{Results and Discussions}

This study was carried out to examine the extent to which the EFL teachers working at PU teach listening strategies and how they understand listening strategies. The study also attempted to investigate the difficulties that EFL teachers encounter when teaching listening comprehension. Below are the results of the three research questions regarding how the EFL teachers at the TDTU perceive listening comprehension, to what extent they teach listening comprehension to the students, and what difficulties these EFL teachers encounter in listening comprehension lessons.

\subsection{Results}

\subsubsection{Results of Research Question 1}

RQ1 attempted to find out the teachers' understanding of listening strategies.

\section{a. Teachers' Perception of the Importance of Teaching Listening Strategies to Students}

Table-1. Usefulness of Listening Strategy Training for Students

\begin{tabular}{l|l|l}
\hline Level of Perceived Usefulness & Frequency & Percent \\
\hline A. Very useful & 28 & $77.8 \%$ \\
\hline B. Somewhat useful & 6 & $16.7 \%$ \\
\hline C. Slightly useful & 2 & $5.5 \%$ \\
\hline D. Not useful at all & 0 & $0 \%$ \\
\hline Total & 36 & $100 \%$ \\
\hline
\end{tabular}

Data displayed in Table 1 show that a majority of the teachers felt that listening strategy training is very useful for the students (77.8\%). $16.7 \%$ of them said that listening strategy training is somewhat useful, whereas only $5.5 \%$ of them indicated that listening strategy training is slightly useful. Results of the interview revealed that all of the teachers said that teaching listening strategies to students is very essential. For example, they expressed: 
“....teaching listening strategies enhances students' listening skills and makes them aware of the format of a typical listening task (T1)....teaching listening strategies serve as a preliminary to help students with different listening task types as well as improve their listening comprehension (T2). It is very important to teach listening strategies to students because if they employ the strategies well, they can improve their English fast and listen effectively (T3). Teaching listening strategies to students is essential as developing listening strategies is prior to developing any others skills of English (T4)...”

\section{b. Teachers' Knowledge of Listening Comprehension Strategies}

Table-2. Teachers' Level of Familiarity with Concept of Listening Strategies

\begin{tabular}{l|l|l|l|l|l}
\hline \multicolumn{2}{l}{ Teaching Listening Approach } & \multicolumn{4}{l}{$\begin{array}{l}\text { Teachers' Level of Familiarity with Concept of } \\
\text { Listening Strategies }\end{array}$} \\
\hline As Discrete skill & As Integrated skill & Not at all & Slightly & Somewhat & Very \\
\hline $19.4 \%$ & $80.6 \%$ & $0 \%$ & $2.8 \%$ & $33.3 \%$ & $63.9 \%$ \\
\hline
\end{tabular}

Data in Table 2 shows that only $19.4 \%$ of the teachers were teaching listening as discrete skill, while a very large majority $(80.6 \%)$ of them confirmed that they were teaching listening as an integrated skill. With regard to the teachers' levels of familiarity in terms of the concept of listening comprehension strategies. It can be seen in Table 2 that listening strategies were fairly known to the teachers; $63.9 \%$ of them identified themselves as being much acquainted with the concept of listening strategies, while $2.8 \%$ of them said they were slightly familiar with the idea of listening strategies, and $33.3 \%$ of them identified themselves as being somewhat familiarity with the concept. A majority of them responded to this item mentioned Compensation, Cognitive and Metacognitive strategies when it comes to teaching listening strategies to students. For example, five of them expressed:

“...I often have my students listen for gist and details (T3). I always ask my students to listen for details, gist; and make prediction or pay attention to the signpost before listening, then I have them infer the meaning of the listening text (T4). Listening for gist, listening for details, guessing the content, inferring the meaning (T6). I ask my students to guess the new words and the main ideas of the listening texts; and I get them to think about the topic they are going to listen (T7). I often employ both top down and bottom up, restructuring the text and mimicking (T8)..."

\section{c. The Challenge of Teaching Listening Strategies}

Seven out of ten teachers said that teaching listening strategies is more difficult than teaching the other skills. For example:

“.....Teaching listening comprehension strategies is a little bit difficult since it is a time consuming practice (T2); ....it is slightly difficult as it is related to cognitive process in students' mind (T4); .... it is a bit difficult because strategies are technical and students may find it hard to apply them when listening (T6); ... it is rather difficult because students may get bored with the strategy lessons (T7); .... it is difficult since it requires a large amount of time and determination from students. Besides, Vietnamese students don't have much listening exercise from the early stages of learning English (T8)..."

On the other hand, three teachers indicated that teaching listening strategies is not a challenging practice so long as these strategies are employed through activities.

"....it is not a tough practice because teaching productive skills such as speaking and writing are more difficult (T3); it is not difficult, since the teacher is good at clarification and modeling (T9); ..if they maintain sufficient practice it is not a challenging task (T10)...."

\section{d. Teachers' Listening Strategy Teaching Practice Routine}

While only one-third of the teachers (3) said that they often went through three stages of the listening strategy process (pre-while-post), the remaining ones confirmed that they often skipped the last stage of the listening strategy. For example, several teachers expressed:

"..... and I often leaves the post listening stage (T1); I often fail to go through three stages since teaching listening strategies is a time consuming practice (T3); I rarely carry out sufficient procedures when teaching listening strategies because I find it rather mechanical and I do not use them very often (T5); ....my students are not interested in listening lessons so they spend most of the time in class learning grammar (T7); ....I do not focus on teaching strategies because strategy will make my students focus on answering the questions but not listening to comprehend the conversation (T9)..."

\section{e. The Effective EFL Listening Comprehension Lessons}

All of the teachers expressed the belief that finding out the topics that interest students on and teach them ways how to listen is the most effective ways of teaching listening comprehension. For example:

“... it is necessary to teach students listening strategies and activities to work on each strategy to help them improve their listening skill;....I often combine a wide range of strategies to help my 
students listen better in classroom listening and real life situations (T3); ...students need to be exposed to spoken English to be able to develop their listening skills and it often takes time and practices to be successful listener, rushing students to listen does not help them out (T8); teachers are supposed to equip themselves with effective strategies, knowledge to motivate their students to keep practice listening either in the classroom or out of the class (T10).

\subsubsection{Results of Research Question 2}

RQ2 attempted to explore the teachers' employment of listening strategies in their instruction. Data collected from the questionnaire was used to address this research question.

\section{a. Memory Strategies}

Table 3 below displays data related to teachers' use memory strategies in listening instruction.

Table-3. Use of Memory Strategies in Instruction

\begin{tabular}{l|l|l|l}
\hline Item No & Content & M & St. D \\
\hline 1 & I ask my students to link their existing knowledge with what they hear. & 3.64 & 1.150 \\
\hline 2 & $\begin{array}{l}\text { I ask my students to classify what they hear into meaningful groups } \\
\text { (e.g. phonology, semantic maps) }\end{array}$ & 3.08 & 1.156 \\
\hline 3 & $\begin{array}{l}\text { I ask my students to form pictures mentally to help them comprehend } \\
\text { the text before listening. }\end{array}$ & 3.36 & 1.291 \\
\hline
\end{tabular}

Data displayed in Table 3 shows that over half of the teachers asked the students to link existing knowledge with what they heard and form pictures mentally to support them in comprehension with $(\mathrm{M}=3.64)$ and $(\mathrm{M}=3.36)$ respectively. Obviously, these two memory strategies were more frequently employed than the rest one.

\section{b. Cognitive Strategies}

Table 4 below displays data related to teachers' use memory strategies in listening instruction

Table-4. Use of Cognitive Strategies in Listening Instruction

\begin{tabular}{l|l|l|l}
\hline Item No & Content & M & St. D \\
\hline 4 & $\begin{array}{l}\text { I teach my students to identify some patterns as whole chunks, such } \\
\text { as "what's the matter" }\end{array}$ & 3.94 & .924 \\
\hline 5 & I make my students practice sounds (pronunciation and intonation) & 3.75 & .996 \\
\hline 6 & I instruct my students how to jot down the key words when listening. & 3.78 & 1.072 \\
\hline 7 & $\begin{array}{l}\text { I use authentic materials such as English radio, English songs, and } \\
\text { everyday conversations in my classroom. }\end{array}$ & 3.81 & 1.064 \\
\hline 8 & I let my students listen to the text at least twice. & 4.33 & .828 \\
\hline 9 & I have my students listen and jot down most of what they hear. & 3.00 & 1.394 \\
\hline 10 & I make my students listen to understand the main idea. & 4.47 & .878 \\
\hline 11 & I have my students listen for detailed information. & 4.47 & .810 \\
\hline 12 & I have my students listen and resolve multiple choice questions. & 4.25 & .770 \\
\hline 13 & I adjust the level of listening tasks when necessary. & 3.92 & 1.105 \\
\hline 14 & I have my students fulfill the comprehension tasks after they listen. & 4.19 & .920 \\
\hline 15 & I use role-play and games when teaching listening. & 3.19 & 1.261 \\
\hline 16 & $\begin{array}{l}\text { I engage my students in listening activities such as making diagrams, } \\
\text { note taking and drawing. }\end{array}$ & 3.56 & 1.081 \\
\hline
\end{tabular}

As shown in Table 4, cognitive strategies were often employed in listening classrooms by a majority of the teachers. Listening to understand the main idea and listening for detailed information were the highest frequentlyused strategies with $(M=4.47)(M=4.47)$ respectively. Next, listening to the text at least twice, listening and doing multiple choice exercises, and doing tasks after listening with $(M=4.33),(M=4.25),(M=4.19)$ respectively were also employed by most of the teachers.

On the other hand, item 18 and 27 were the two least frequently employed strategies in the listening lessons (M= 3.19) $(\mathrm{M}=3.00)$ respectively. It was evident that not many of the teachers used role-play and games during instruction and asked the students to jot down what they heard. The data also revealed that about three-fourths of the teachers employed the remaining strategies (items 4,5,6,7,13,16) with $(\mathrm{M}=3.94),(\mathrm{M}=3.75), \quad(\mathrm{M}=3.78), \quad(\mathrm{M}=3.81)$, $(\mathrm{M}=3.92)$, and $(\mathrm{M}=3.56)$ respectively.

\section{c. Compensation Strategies}

Table 5 below displays the data regarding the use of compensation strategies in listening instruction. 
Table-5. Use of Compensation Strategies in Instruction

\begin{tabular}{l|l|c|c}
\hline Item No & Content & M & St. D \\
\hline 17 & $\begin{array}{l}\text { I teach my students various techniques to guess the meanings of unfamiliar } \\
\text { words. }\end{array}$ & 3.94 & .893 \\
\hline 18 & $\begin{array}{l}\text { I ask my students questions with who, how, when, where, and what about the } \\
\text { listening text before they listen. }\end{array}$ & 4.47 & .774 \\
\hline 19 & $\begin{array}{l}\text { I stop the recording at the middle of the listening process and ask my students } \\
\text { to guess what is coming next. }\end{array}$ & 3.11 & 1.260 \\
\hline
\end{tabular}

Regarding the use of compensation strategies, it is apparent that three compensation strategies were frequently integrated into instructions by the teachers. Turning first is item 18 with $(M=4.47)$. That means nearly all of the teachers asked Wh-questions to elicit ideas from the students before they listened to the text. Moreover, most of the teachers taught the students how to guess the meaning of words (item 17) with $(\mathrm{M}=3.94)$, whereas only nearly a half of the teachers said that they often stopped the recording at the middle of the listening process and asked their students to guess what was coming next before returning to listening task (item 19) with $(\mathrm{M}=3.11)$.

\section{d. Metacognitive Strategies}

Table 6 below displays the data regarding the use of metacognitive strategies in listening instruction.

Table-6. Use of Metacognitive Strategies in Instruction

\begin{tabular}{l|l|l|l}
\hline Item No & Content & M & St. D \\
\hline 20 & I teach topic relating vocabulary prior to listening. & 4.19 & .822 \\
\hline 21 & $\begin{array}{l}\text { I make my students think over the vocabulary related to the listening text } \\
\text { they already know. }\end{array}$ & 3.64 & 1.175 \\
\hline 22 & I provide my students with precise answers directly after listening exercise. & 3.25 & 1.273 \\
\hline 23 & I instruct my students how to check their understanding while listening. & 3.64 & 1.073 \\
\hline 24 & I encourage my students to use checklist to measure their listening progress. & 2.86 & 1.355 \\
\hline 25 & I ask my students to practice English listening actively in daily lives. & 4.36 & .899 \\
\hline 26 & I have my students set objectives for listening practice. & 3.78 & 1.174 \\
\hline
\end{tabular}

It can be seen in Table 6, regarding the use of metacognitive strategy, the data shows that most of the teachers strongly encouraged their students to practice listening outside of the class (item 25) with (M=4.36) and supported the idea of teaching topic related to vocabulary prior listening (item 20) with $(M=4.19)$. Meanwhile, about threefourths of them asked their students to think over the vocabulary related to the listening text, check their understanding while listening, and set objectives for listening practice. (items $21,23,26)$ with $(\mathrm{M}=3.64,3.64,3.78$ ) respectively. On the other hand, only nearly a half of the confirmed that they often told their students the correct answer directly after listening tasks, and encouraged them to keep diaries, checklists, or notebook for measuring their progress in listening (Items 22,24) with (M=3.25, (M=2.86) respectively.

\section{e. Affective Strategies}

Table 7 displays the data regarding the use of affective strategies in listening instruction

Table-7. Use of Affective Strategies in Instruction

\begin{tabular}{l|l|l|l}
\hline Item No & Content & M & St. D \\
\hline 27 & I encourage my students to be calm and not be nervous when listening to the text. & 4.08 & .874 \\
\hline 28 & I teach my students techniques to deal with their anxiety when listening. & 3.53 & 1.276 \\
\hline 29 & I tell my students what listening problems they have. & 3.83 & .971 \\
\hline
\end{tabular}

Table 7 shows the data relating to the teachers' use of affective strategies. It can be seen that all the affective strategies were integrated into listening instructions.

The data shows that over half of the teachers used these strategies (Items 28,29,27) in their listening instruction with $(\mathrm{M}=3.53),(\mathrm{M}=3.83),(\mathrm{M}=4.08)$ respectively.

\section{f. Social Strategies}

Table 8 displays the data regarding the use of social strategies in listening instruction

Table-8. Use of Social Strategies in Instruction

\begin{tabular}{l|l|l|l}
\hline Item No & Content & M & St. D \\
\hline 30 & I teach my students the cultures relating to the listening text before listening. & 3.25 & 1.025 \\
\hline 31 & I encourage my students to pay attention to others' thoughts and feelings. & 3.28 & 1.031 \\
\hline 32 & $\begin{array}{l}\text { I tell my students to pay attention to the speakers' vocal patterns and } \\
\text { behavioral characteristics (whenever they can see the speakers) }\end{array}$ & 3.53 & 1.444 \\
\hline
\end{tabular}


Regarding the use of social strategies, data displayed in Table 8 shows that over half of the teachers said they always or often told their students to listen to speakers very carefully and observe their behavior at the same time whenever they can see the speakers (item 32) with $(\mathrm{M}=3.53)$. However, not many teachers encouraged students to pay attention to others' thoughts and feelings taught their students target cultures relating to the text (Items 31,30 ) with $(\mathrm{M}=3.28),(\mathrm{M}=3.25)$ respectively.

\subsubsection{Results of Research Question 3}

RQ3 attempted to investigate the difficulties that teachers encounter when teaching listening comprehension.

\section{a. Difficulties Arising from Teachers' Knowledge and Attitudes}

Data collected regarding difficulties arising from teachers' proficiency is displayed in Table 9 below.

Table-9. Difficulties Arising from Teachers' Proficiency

\begin{tabular}{l|l|l|l}
\hline Item No & Content & M & St. D \\
\hline 33 & Teachers sometimes take short-term training courses in teaching listening. & 1.75 & .996 \\
\hline 34 & $\begin{array}{l}\text { There are many ways of improving existing teaching experience in teaching } \\
\text { listening. }\end{array}$ & 2.03 & 1.183 \\
\hline 35 & Teachers seem lack of enthusiasm for teaching listening comprehension. & 2.44 & 1.297 \\
\hline 36 & Teaching listening comprehension methods are too difficult. & 2.81 & 1.167 \\
\hline 37 & I lack teaching listening comprehension experience. & 2.69 & 1.261 \\
\hline 38 & Unexpected problems arising from listening comprehension are difficult to solve. & 2.69 & 1.238 \\
\hline 39 & It is not required special knowledge or effort to teach listening comprehension. & 2.17 & .971 \\
\hline 40 & Listening comprehension strategies and methods are crucial and necessary. & 4.08 & 1.156 \\
\hline
\end{tabular}

Data displayed in Table 9 shows that nearly all of the teachers did not think that they sometimes took training courses in teaching (item 33) with $(\mathrm{M}=1.75)$; about three-fourths of them did not think that they could improve their teaching experience by many ways (item 34) (M=2.03). However, over half of them opposed the idea that they were not motivated when teaching listening comprehension (item 35) with (M=2.44) and about one-third of them said that they sometimes encountered potential problems relating to listening teaching method (item36) with $(\mathrm{M}=2.81$ ). Particularly, about half of them thought that they lacked teaching experience and having difficulties in dealing with unexpected problems (items 37,38) with $(\mathrm{M}=2.69)$ and $(\mathrm{M}=2.69)$ respectively. Very few teachers thought that they did not need special knowledge and effort to teach listening skill (item 39) with $(\mathrm{M}=2.17)$ and most of them agreed that listening strategies and methods are necessary (item 40) with $(\mathrm{M}=4.08)$.

\section{b. Difficulties Arising from the Teaching Environment}

Table 10 displays the data regarding difficulties arising from the teaching environment.

Table-10. Difficulties Arising from the Teaching Environment

\begin{tabular}{l|l|c|c}
\hline Item No & Content & M & St. D \\
\hline 41 & Electricity supplies are not available. & 2.19 & 1.238 \\
\hline 42 & There are insufficient well equipped rooms to teach listening skills at school. & 2.83 & 1.404 \\
\hline 43 & The classroom is uncomfortable and disturbing. & 2.83 & 1.159 \\
\hline 44 & The classroom is not ready for teaching listening. & 2.78 & 1.245 \\
\hline 45 & Distractions (visuals \& auditory) are not minimized. & 2.94 & 1.145 \\
\hline 46 & $\begin{array}{l}\text { The remaining skills of the language are more important than listening } \\
\text { comprehension. }\end{array}$ & 1.92 & 1.025 \\
\hline 47 & It is not helpful to use media (TV, Radio...) while teaching listening. & 1.78 & 1.198 \\
\hline 48 & $\begin{array}{l}\text { There is no significant contribution to incorporate technology into teaching } \\
\text { listening skill. }\end{array}$ & 1.83 & .971 \\
\hline 49 & The class size is appropriate for teaching listening comprehension. & 2.53 & 1.158 \\
\hline
\end{tabular}

Data displayed in Table 10 shows that not many of the teachers had difficulties relating to the teaching environment. It was evident that one difficulty that about half of the teachers encountered was the large number of the students in each class (item 49) with $(\mathrm{M}=2.53)$. However, it can be said that not all teachers were satisfied with the teaching environment. For example, only about half of the teachers thought that the classrooms were well equipped (item 42) with ( $\mathrm{M}=2.83)$.

\section{c. Difficulties Arising from Teaching Resources}

Table 11 displays data regarding difficulties arising from teaching resources. 
Table-11. Difficulties Arising from Availability of Resources and Teaching Aids

\begin{tabular}{l|l|l|l}
\hline Item No & Content & M & St. D \\
\hline 50 & $\begin{array}{l}\text { The text book is an invaluable tool presenting methods of listening } \\
\text { comprehension teaching. }\end{array}$ & 2.94 & 1.094 \\
\hline 51 & $\begin{array}{l}\text { Textbooks and teacher's books seem not to provide activities integrated } \\
\text { with listening comprehension. }\end{array}$ & 2.86 & 1.073 \\
\hline 52 & $\begin{array}{l}\text { Textbooks and teacher's books seem not to provide teachers with } \\
\text { guidelines throughout their teaching listening comprehension. }\end{array}$ & 2.67 & 1.095 \\
\hline 53 & $\begin{array}{l}\text { There are insufficient tools (recordings, CDs, cassettes...) used to activate } \\
\text { listening skill. }\end{array}$ & 2.97 & 1.108 \\
\hline 54 & There is a lack of authentic listening material input. & 2.94 & 1.068 \\
\hline 55 & There seem to be quite a few listening tasks available in the textbooks. & 3.06 & .984 \\
\hline
\end{tabular}

Data displayed in Table 11 shows that only nearly half of the teachers had difficulties regarding the teaching resources except that most of the teachers thought that methods of teaching listening were not introduced in the text book (item 50) with $(\mathrm{M}=2.94)$, and over half of the teachers were not satisfied with listening tasks in the text book (item 55) with $(\mathrm{M}=3.06)$. However, most of the teachers thought that the text book provided activities integrated with listening activities (item 51) with $(\mathrm{M}=2.86)$, guidelines for teaching listening (Item 52) with $(\mathrm{M}=2.67)$, tools for listening (item 53) with $(\mathrm{M}=2.97)$, and authentic material input (item 54) with $(\mathrm{M}=2.94)$.

\section{d. Difficulties Arising from Students' proficiency and attitudes}

Table 12 below displays data regarding difficulties arising from students' proficiency and attitudes

Table-12. Difficulties Arising from Students' Proficiency and Attitudes

\begin{tabular}{l|l|l|l}
\hline Item No & Content & M & St. D \\
\hline 56 & $\begin{array}{l}\text { My students have problems listening to texts that there are many unfamiliar } \\
\text { words. }\end{array}$ & 4.08 & 1.079 \\
\hline 57 & $\begin{array}{l}\text { My students have problems listening to texts that contain complex grammar } \\
\text { structures. }\end{array}$ & 3.53 & 1.082 \\
\hline 58 & My students have problems listening to long texts. & 4.22 & .898 \\
\hline 59 & My students have problems understanding the unfamiliar listening topic. & 4.14 & .931 \\
\hline 60 & My students have problems recognizing the words they already know. & 3.11 & 1.166 \\
\hline 61 & My students have problems taking notes when listening. & 3.58 & 1.079 \\
\hline 62 & $\begin{array}{l}\text { My students have problems understanding the listening texts at the first time of } \\
\text { listening. }\end{array}$ & 3.58 & .996 \\
\hline 64 & $\begin{array}{l}\text { My students feel anxious and worried when they do not understand the listening } \\
\text { texts. }\end{array}$ & 3.94 & .893 \\
\hline 65 & $\begin{array}{l}\text { My students have problems comprehending the meaning of listening texts without } \\
\text { seeing the speaker's gestures. }\end{array}$ & 2.81 & 1.215 \\
\hline
\end{tabular}

Table 12 shows the difficulties relating to students' proficiency and attitudes. It is clear that three of the most problems that teachers often encounter were that students faced many unfamiliar words (item 56) with (M=4.08), listened to long texts (item 58) with ( $=4.22)$, and unfamiliar topics (item 59) with $(\mathrm{M}=4.14)$. The students were anxious and worried of understanding of listening texts (item 63) and listening to unfamiliar accents (item 65) with $(M=3.94)$ and $(M=3.58)$ respectively. Items 57 and 61 revealed that about half of the teachers encountered the difficulties that their students sometimes could not understand the texts because of grammar and inability to take notes with $(\mathrm{M}=3.53)$ and $(\mathrm{M}=3.58)$ respectively. More interestingly, very few teachers thought that their students did not have problems in recognizing the words they already know $(M=3.11)$ and in understanding listening texts without seeing speakers' body language $(\mathrm{M}=2.81)$ caused them problems.

\subsection{Discussions}

Regarding teachers' perceptions of listening strategies, the findings of the study revealed that a large number of the teachers strongly expressed their view that teaching listening strategies to students is very important due to various positive impacts on EFL students. This finding is consistent with those of Siegel (2013), Vandergrift and Tafaghodtari (2010) who emphasized the considerable benefits that listening strategies have yielded. Listening strategies can enhance the students' listening skill and improve their confidence and motivation (Cross, 2011; Yan, 2012; Yeldham and Gruba, 2016). Students can use listening strategies as a valuable tool to fulfill the tasks and assess their own comprehension and responses (Vandergrift, 1999). In terms of teachers' knowledge of listening comprehension strategies, the findings of the study revealed that most of the teachers referred to social-affective strategy, cognitive and metacognitive strategies when teaching listening comprehension since these strategies may be easily adapted to the levels of students. Regarding the challenge of teaching listening strategies, over two-thirds of the teachers confirmed that teaching listening strategies is a challenging practice. It can be inferred that they preferred traditional teaching methods. They failed to engage students in listening lessons for these difficulties. This 
study produced results which corroborate the findings of a great deal of the previous work in this field by Do (2007), Vu and Shah (2016), Luu and Phung (2013), Nguyen (2017). As a result, most of the teachers confirmed that they often fail to go through three stages or they sometimes cut short the process of listening strategies when teaching this skill due to the limitation of time, which might not facilitate the process of listening, easily leading to failure in listening to long or difficult texts.

Regarding the extent to which the teachers teach listening strategies to their students, the findings of the study revealed that not all the strategies were frequently employed by the teachers. Several strategies of each type were more frequently employed than the others. It was evident that only about half of the teachers employed memory strategies during listening lessons. It might be because the teachers thought that it was time-consuming or that their students were unable to apply these strategies. Another reason might be that all listening tasks are ready-made and the teachers only chose those easy ones for their students to practice listening skill. Nonetheless, it was evident that cognitive strategies were the most frequently integrated into listening instruction. That might be because cognitive strategies involve a number of mental activities that are essential for completing a task.

The findings also showed that teachers often have their students listen to the text at least twice prior to performing the listening tasks. This finding is in agreement with Oxford (1990) findings which showed that listening to something over and over, particularly the authentic input enhances students' comprehension, confidence and develop fluency in language students considerably. In addition, teachers often adjust the level of listening texts by selecting the appropriate authentic materials, or engage their students with the activities such as sound, pattern practice and note taking to help them minimize their listening problems when performing listening tests. This finding further supports the idea of using authentic materials in classes may minimize difficulties in listening comprehension (Ak, 2012; Mc Bride, 2011). Nonetheless, it must also be affirmed that most of the listening tasks in the text book were designed based on these strategies, so it might be easy for the teachers to implement their listening activities.

With respect to compensation strategies, the findings of the study showed that teachers often asked their students the interrogative Wh-questions relating to the topic or teach them various techniques to predict the meaning of the unfamiliar words prior to listening. This finding seems to be consistent with Chang (2008) which indicated that previewing the questions prior to listening is extremely helpful to students' comprehension. These strategies helps students with linguistic limitations comprehend the overall meaning; by using linguistic clues and other clues listeners may understand a great deal of listening without understanding every single word (Oxford, 1990).

With regard to the metacognitive strategies, the results showed that the teachers often encouraged students to listen for general and specific information to answer the questions. Obviously, these two strategies are very common to teachers and they are easy for them to apply in their instruction. However, the finding showed that very few teachers gave direct feedback in the form of right answers. This finding failed to support the previous study that providing students with positive answers is regarded as broadening experience of success that helps avoid the mental obstacles (Krashen, 1982). Furthermore, although the teachers encourage their students to practice listening outside of the class, they rarely tell the students to keep checklists to measure their own listening progress. However, this finding differs from Oxford (1990) findings which revealed that recording goals and objectives in a notebook to track the process of the language learning can help students set long term and short term aims for practice listening. It may conclude that teachers have the students focus on the results of the listening tests rather than practice the listening skill (Do, 2007).

In relation to the social-affective strategies, the results indicated that three of the affective strategies were integrated into listening instruction. Although teachers often encouraged their students to be calm and point out the potential problems that student encountered during the listening, they rarely taught them techniques to deal with these potential problems. This finding fails to support the idea of Vandergrift (2003) who indicated that socialaffective strategies are regarded as skills which students use to work with others to show understanding or to deal with anxiety to feel confident when listening; by doing so, it may help improve their listening skill. In addition, the findings showed that teachers asked their students to pay attention to the speakers' voices and their behavior rather than the other thoughts and feelings. Nonetheless, teachers rarely use role play games or teach their students the target cultures when teaching listening. That might be because the teachers lack cultural knowledge of the target language or they might not know about this strategy.

Regarding difficulties encountered by the teachers during the implementation of listening lessons, the findings of the study revealed that the teachers encountered difficulties in relation to teachers' knowledge and attitudes, the teaching environment, teaching resources and the students. Regarding teachers' knowledge and attitudes, the findings of the study revealed that most of the teachers thought that taking training courses in teaching listening skill is important. It can be inferred that they have difficulties in application of listening teaching techniques or strategies. Training courses may help them address this problem. Nonetheless, most of them did not receive sufficient training courses. In-service training courses help teachers increase their knowledge and pedagogy. That is why about onethird of them thought that they lacked experience in teaching listening and nearly half of them had difficulties in dealing with potential listening comprehension. Experienced teachers know how to select appropriate activities for students' different levels, motivate students and monitor them during the lesson. Undoubtedly, if they are welltrained, experienced and enthusiastic enough, they may deal with difficulties more easily during instruction. 
In terms of difficulties arising from the teaching environment, the findings of the study revealed that most of the teachers did not have difficulties relating to the learning environment. That might be because recently PU has rapidly improved its facilities for teaching and learning EFL. Although the findings showed that several teachers had difficulties with large class size. That might be because they lacked experience in organizing activities for large classes. Mixed ability classes do not really cause problems if teachers know how to put students into groups and give different assignments to different students.

With regard to difficulties arising from teaching resources, the findings of the study revealed that not many of the teachers encountered difficulties in their instruction except that nearly half of the teachers thought that the text book did not present methods of teaching listening comprehension. This finding is in agreement with Mendelsohn (1998) point of view that textbooks in fact do not sufficiently develop metacognitive knowledge through raising students' consciousness of listening process. Thus, it is necessary to teach students how to listen (Vandergrift, 2002). The findings also revealed that over one-third of the teachers did not think there are enough listening tasks in the textbook. These teachers seemed to expect the text books could provide a wide range of listening tasks. It might be because teachers with minimum teaching experience seem to depend on the textbook and on the teacher's book for the specific guidelines. Teachers should know how to adapt the textbook and design learning activities to meet students' different levels and preferences.

With respect to difficulties arising from students' proficiency and attitudes, the findings of the study showed that the teachers had problems because the students could not understand listening texts. That is because of long texts and unfamiliar topics, leading to their anxiety. It is evident that the topics in the textbooks might not be very interesting and might be more difficult in comparison with the students' levels. Topics should generate motivation and concentration in students (Underwood, 1989). Students often feel demotivated because of not being able to understand the spoken text since their teachers often ask them to understand all the words presenting in the listening (Underwood, 1989). Having a lot of unfamiliar words and accents also causes problems in understanding of the text. Yousafi (2006) found that unknown words are regarded as the main factors that interfere with listening comprehension. This finding is in accordance with the findings of Zhao (1997) which argued that unfamiliar accents and unclearly pronounced words are considered as the factors that influence listening comprehension. It may be interpreted that listening texts designed in the textbooks are inappropriate to students' existing knowledge and interests. It is the teacher's responsibility to make them more interesting and suitable to their students' level so that they can lower students' anxiety and demotivation.

\section{Conclusion and Implications}

This study has shown interesting information about the teachers' perception of listening strategies, practice of teaching listening strategies and difficulties encountered during instruction. The study has once emphasized the significance of teaching listening strategies to EFL students; and it proves that most of the teachers are likely to succeed in employing these strategies effectively while giving listening comprehension lessons. However, the findings showed that several strategies including memory strategies, metacognitive strategies, and social strategy are less frequently integrated strategies into instruction. It is suggested that teachers apply these listening strategies more frequently. In addition, teachers are supposed to improve their time management skills when delivering listening lessons to make sure that all of the stages of the listening lesson should be completely covered. One more important thing is that textbooks may cause difficulties for both teachers and students. Textbook adaptation is necessary for any EFL class. It is the teacher's responsibility to do this task. Only by doing so, teachers can overcome difficulties in their listening instruction. Regarding difficulties encountered in instruction, the class size is the most serious problem teachers often encounter, so reduction in class size is a must to ensure the classroom interaction between students and their teachers. Other problems relating to long texts, unfamiliar topics, unclear pronounce words, and unfamiliar accents can be tackled if the teachers provide students with sufficient knowledge vocabulary relating to topics, or sounds practice prior to listening. Furthermore, it is advisable that various listening texts for input should be selected so that students can familiarize with various accents to lower their anxiety when listening or enhance their note taking skill. Least but not last, professional development must not be neglected in any case. Teachers, especially those who are less experienced always need to take short-term training courses so that they can fill the gap in their knowledge and experience.

\section{References}

Ak, S. (2012). Pronunciation awareness training as an aid to developing EFL students' listening comprehension skills. (Unpublished master's thesis), The program of teaching English as a foreign language, Bilkent University, Ankara, Turkey.

Alrawashdeh, I. A. and Al-zayed, N. N. (2017). Difficulties that English teachers encounter while teaching listening comprehension and their attitudes towards them. English Language Teaching, 10(5): 167-77.

Benson, M. J. (1994). Lectures listening in an ethnographic perspective. In J. Flowerdew (Eds.). Academic listening. Cambridge University Press: Cambridge. 181-98.

Brown (1994). Principles of language learning and teaching. Prentice Hall: New Jersey.

Brown, G. (1995). Dimensions of difficulty in listening comprehension. In D. J. Mendelsohn \& J. Rubin (Eds.). A guide for the teaching of second language listening. Dominie: San Diego. 59-73.

Chamot, A. U. (1995). Learning strategies and listening comprehension. In D. J. Mendelsohn \& J. Rubin (Eds.). A guide for the teaching of second language listening. Dominie: San Diego. 13-30. 
Chang, C. S. (2008). Listening strategies of L2 students with varied test tasks. TESL CANADA Journal, 25(2): 1-22.

Chaugule, S. S. (2009). The communicative approach to language teaching. Available: http://www.articlesbase.com

Chen, S. W. (2002). Problems in listening comprehension for students of EFL. Studies in English Language and Literature, 10: 57-70.

Cross, J. (2011). Metacognitive instruction for helping less skilled listeners. ELT Journal, 65(4): 408-16.

Demirkol, T. (2009). An investigation of Turkish preparatory class students listening comprehension problems and perceptual learning styles.

Do, T. M. C. (2007). Teaching listening comprehension at Food Industry College of Ho Chi Minh City. (Unpublished master's thesis) University of Social Sciences \& Humanities, Ho Chi Minh City, Vietnam.

Eltaib, A. S. (2011). Difficulties of teaching listening skill in large classes. (Published master's thesis). Sudan University.

Ferris, D. (1998). Students' views of academic aural/oral skills, A comparative needs analysis. TESOL Quarterly, 32(2): 289-318.

Field, J. (2002). The changing face of listening, In J. Richards \& W. A. Renandya (Eds), Methodology in language teaching, An Anthology of current practice. Cambridge University Press: Cambridge. 1-3.

Goh (2000). A cognitive perspective on language students' listening comprehension problems. System, 28(1): 55-77.

Goh (2002). Exploring listening comprehension tactics and their interaction patterns. System, 30(2): 185-206.

Graham, S. (2006). Listening comprehension The students' perspectives. System, 34(2): 165-82.

Hamouda, A. (2013). An investigation of listening comprehension problems encountered by Saudi Students in the el listening classroom. International Journal of Academic Research in Progressive Education and Development, 2(2): 113-55.

Hargreaves, A. and Fullan, M. G. (1992). Understanding teacher development. Teachers College Press: New York.

Hasan, A. S. (2000). Students' perceptions of listening comprehension problems. Language Culture and Curriculum, 13(2): 137-53.

Higgins, J. M. D., 1996. "Students' listening difficulties, The contribution of speech rate. In C. Zaher (Eds)." In Proceedings of the third EFL skills conference: New directions in listening (pp. 65-75). Cairo: The American university in Cairo.

Ho, B. (2011). Solving the problems of designing and teaching a packed English for specific purposes course. New Horizon in Education, 59(1): 119-36.

Hutchison, T. and Torres, E. (1994). The textbook as agent of change. ELT Journal, 48(4): 315-28.

Juan, W. X. and Abidin, M. J. Z. (2013). English listening comprehension problems of students from China learning English in Malaysia. School of educational studies. University Sains Malaysia: Penang, Malaysia.

King, P. and Behnke, R. R. (2003). Patterns of state anxiety, task directed affect, and listening performance. International Communication Association, 24(2): 146-78.

Krashen, S. D. (1982). Principle and practice in second language acquisition. Oxford Pergamon.

Lonsdale, R., 1996. "International student listening problems in a British institution of a higher education. In C. Zaher (Eds)." In Proceedings of the third EFL skill conference, New directions in listening Cairo: The American University in Cairo. pp. 44-54.

Luu, Q. K. and Phung, N. Q. N. (2013). A study of difficulties faced by EFL teachers in teaching listening at high schools in Nghe An province, A case study with currently used textbook tieng Anh 11. Sciences and Technology Journal, 63(2): 64-70.

Lynch, T. (2002). Listening, Questions of level. In R. Kaplan (Eds.) The Oxford handbook of applied linguistics. Oxford University Press: New York. 39-48.

Masuhara, H. and Tomlinson, B. (2008). Materials for general English, In B. Tomlinson (Eds.) English language learning materials, A critical review. Continuum: London. 17-37.

Mc Bride, K. (2011). The effect of rate of speech and distributed practice on the development of listening comprehension. Computer Assisted Language Learning, 24(2): 131-54.

McGrath, I. (2002). Materials evaluation and design for language teaching. Edinburgh University Press: Edinburgh.

McNeill, A., 1996. "Some formal obstacles to grasping meaning in spoken English. In C. Zaher (Eds)." In Proceedings of the third EFL skill conference, New directions in listening Cairo, The American University in Cairo. pp. 80-88.

Mendelsohn, D. J. (1994). Learning to listen. Dominie Press: USA.

Mendelsohn, D. J. (1995). Applying learning strategies in the second/foreign language listening comprehension lesson. In D. J. Mendelsohn \& J. Rubin (Eds). A guide for the teaching of second language listening. Dominie: San Diego. 132-50.

Mendelsohn, D. J. (1998). Teaching the language skills, Annual review of applied linguistics. Cambridge University Press: Cambridge.

Nadig, L. A. (1999). Tips on effective listening. Available: http://www.drnadig.com/listening.htm

Nguyen, T. M. H. (2017). Models of mentoring in language teacher education. Springer: New York.

O’Malley, J. M. and Chamot, A. U. (1990). Learning strategies in second language acquisition. Cambridge University Press: Cambridge. http://dx.doi.org/10.1017/CBO9781139524490

O’Malley, J. M., Chamot, A. U. and Kupper, L. (1989). Listening comprehension strategies in second language acquisition. Applied Linguistics, 10(4): 418-37.

O’Malley, J. M., Chamot, A. U., Stewner-Manzanares, G., Küpper, L. and Russo, R. (1985). Learning strategies used by beginning and intermediate ESL students. Language Learning, 35(1): 21-46. 
Oxford, R. L. (1990). Language learning strategies, What every teacher should know. Heinle \& Heinle: Boston.

Peterson, P. W. (2001). Skills and strategies for proficient listening, In M. Celce-Murcia (Ed.) Teaching english as a second or foreign language. Heinle \& Heinle: Boston. 87-101.

Richards, J. C. (1996). Teachers' maxims in language teaching. TESOL Quarterly, 30(2): 281-96.

Rixon, S. (1981). The design of materials to foster particular listening strategies, In the teaching of listening comprehension. The British Council: London.

Rixon, S. (1986). Developing listening skills. Macmillan: London.

Rost, M. (1990). Listening in language learning. Longman: London.

Rost, M. (2002). Teaching and researching listening. Pearson Education: Harlow.

Rubin, J. (1995). The contribution of video to the development of competence in listening. In D.J. Mendelsohn, \& J. Rubin (Eds.) A guide for the teaching of second language listening. Dominie: San Diego. 151-65.

Sheldon, L. (1987). ELT textbook and materials, Problems in evaluation and development. Modern English publications: Oxford.

Siegel, J. (2013). Second language students' perception of listening strategy instruction. Innovation in Language Learning and Teaching, 7(1): 1-18.

Swales, J. (1980). ESP, The textbook problem. The ESP Journal, 1(1): 11-23.

Tauroza, S. (1997). Using students' listening comprehension problems. Perspectives, 9: 161-76.

Thompson, I. (1995). Assessment of second/foreign language listening comprehension. In D. J. Mendelsohn, \& J. Rubin (Eds.). A guide for the teaching of second language listening. Dominie: San Diego. 31-58.

Tomlinson, B. (2003). Developing materials for language teaching. Continuum: London.

Tomlinson, B. (2008). English language learning materials, A critical review. Continuum: London.

Underwood, M. (1989). Teaching listening. Longman: New York.

Ur, P. (1984). Teaching listening comprehension. Cambridge University Press: Cambridge.

Ur, P. (1996). A course in language teaching, Practice and theory. Cambridge University Press: Cambridge.

Ur, P. (2000). Listening comprehension, Beijing people education press \& foreign language teaching and research. Cambridge Press: Cambridge.

Vandergrift, L. (1999). Facilitating second language listening comprehension, acquiring successful strategies. ELT Journal: 168-76.

Vandergrift, L. (2002). Listening, Theory and practice in modern foreign language competence. Good Practice Guide: Available: http://www.llas.ac.uk/resources/gpg/67\#ref15

Vandergrift, L. (2003). Orchestrating strategy use, Towards a model of The Skilled L2 Listener. Language Learning, 53(3): 461-91.

Vandergrift, L. and Tafaghodtari, M. H. (2010). Teaching L2 students how to listen does make a difference, An empirical study. Language Learning, 60(2): 470-97.

Vu, H. Y. and Shah, M. (2016). Vietnamese students' self-direction in learning English listening skills. Asian Englishes, 18(1): 53-66.

Yan, R. (2012). Improving English listening self-efficacy of Chinese university students, Influences of learning strategy training with feedback on strategy use and performance (Unpublished Doctoral Dissertation). Available: http://etheses.dur.ac.uk/3503

Yeldham, M. and Gruba, P. (2016). The development of individual students in an 12 listening strategies course. Language Teaching Research, 20(1): 9-34.

Yen, A. C. (1987). An assessment of listening comprehension difficulties encountered by Chinese college English majors (Unpublished master's thesis), National Taiwan Normal University, Taipei, Taiwan.

Yousafi, A. A. (2006). Listening comprehension difficulties as perceived by [Sic]. Languages \& Translation, 19(1): $35-47$.

Yukselci, S. (2003). Teachers' practices and perceptions regarding listening strategies, and perceptions of difficulties likely to arise in English listening comprehension lessons. (Unpublished master's thesis), Bilkent University.

Zhao, Y. (1997). The effects of listeners' control of speech rate on second language comprehension. Applied Linguistics, 18(1): 49-68. 